\title{
Antidepressant effect of methanol root bark extract of Acacia seyal Del. (Fabaceae): Possible involvement of the inflammatory pathway
}

\author{
Aishatu Shehu*, Bishio Anyip, Mohammed Garba Magaji \\ Department of Pharmacology and Therapeutics, Ahmadu Bello University, Zaria, Nigeria \\ *For correspondence: Email: pharmaishatu@gmail.com; Tel: +234-803-6028298 \\ Sent for review: 22 February 2020 \\ Revised accepted: 14 June 2020
}

\begin{abstract}
Purpose: To study the involvement of inflammatory pathways in the antidepressant activity of Acacia seyal in mice.

Methods: The median lethal dose (LD50) of the extract Acacia seyal (AS) was determined using OECD guideline 425. The antidepressant activity of AS was assessed against BCG $(0.2 \mathrm{mg} / \mathrm{kg}$, ip)-induced depression in mice using Tail suspension test (TST) and open field test (OFT) at 4, 24 and 48 hours post BCG administration.

Results: The median lethal dose (LD50) for the extract was $>5000 \mathrm{mg} / \mathrm{kg}$ orally. The extract AS at all tested doses $(250-1000 \mathrm{mg} / \mathrm{kg})$ significantly $(p \leq 0.001)$ decreased the duration of immobility in TST but increased the number of line crossing in OFT post-BCG.

Conclusion: The antidepressant activity of the methanol root bark extract of Acacia seyal in mice may involve an inflammatory mechanism. Thus, the extract of Acacia seyal may be suitable for the management of depression in humans resistant to other conventional antidepressant agents. However, further studies are required to ascertain this
\end{abstract}

Keywords: Depression, Acacia seyal, Tail suspension test, Open field test, Bacillus Calmette-Guerin

\begin{abstract}
This is an Open Access article that uses a fund-ing model which does not charge readers or their institutions for access and distributed under the terms of the Creative Commons Attribution License (http://creativecommons.org/licenses/by/4.0) and the Budapest Open Access Initiative (http://www.budapestopenaccessinitiative.org/read), which permit unrestricted use, distribution, and reproduction in any medium, provided the original work is properly credited.

Tropical Journal of Pharmaceutical Research is indexed by Science Citation Index (SciSearch), Scopus, International Pharmaceutical Abstract, Chemical Abstracts, Embase, Index Copernicus, EBSCO, African Index Medicus, JournalSeek, Journal Citation Reports/Science Edition, Directory of Open Access Journals (DOAJ), African Journal Online, Bioline International, Open-J-Gate and Pharmacy Abstracts
\end{abstract}

\section{INTRODUCTION}

Depression is an incapacitating psychiatric ailment that has been estimated to affect $21 \%$ of the world population [1]. Depression can occur at any age from childhood to late life and is a tremendous burden to the society. The disorder causes severe distress and disruption of life linked to all-cause mortality [2]. Depression is a highly complicated disorder with heterogeneity observed in etiology, diagnosis and treatment response [3]. Heterogeneity in depression hinders progress in treatment and research [4]. Although a number of drugs are available for the treatment of depressive disorders, most of drugs produces poor response, relapse and remission conferring great challenge [5]. Inflammatory pathways play a role in the pathophysiology of depression and this can be highly beneficial in forming basis for new treatment approaches [6]. The release of pro-inflammatory cytokines leads to neuroinflammation, which contributes to 
depression [7]. Inflammation reduces the availability of serotonin in the brain [8]. Therefore, antidepressant drugs required activation of the inflammatory pathways to increase the synaptic availability of serotonin. Antidepressants are likely to be less effective in the presence of inflammatory stimulus to reduce the depressive symptoms especially in major depression [9]. Excessive production of inflammatory mediators by macrophages has been linked to suicidal attempts [10]. Thus, an urgent need to target inflammatory pathways as an alternative approach to the management of depression. Acacia seyal is reported useful in the management of depression elicited via monoaminergic, neuroendocrine and neurotrophic pathways [11].

However, the involvement of the antiinflammatory mechanism in the antidepressant activity of the plant has not been reported. This study therefore aimed to determine the antidepressant effect of methanol root bark extract of Acacia seyal against Bacillus CalmetteGuerin (BCG) induced depression in mice.

\section{EXPERIMENTAL}

\section{Plant preparations and extraction}

The whole plant Acacia seyal was collected in March 2018 from Sabon Gari Local Government Area of Kaduna State. It was taken to Herbarium Section of the Department of Botany, Ahmadu Bello University, Zaria where it was authenticated by Mr Namadi Sanusi. A voucher specimen (no. 900347) was deposited in the Herbarium of Department of Botany, Ahmadu Bello University, Zaria.

The root bark extract of Acacia seyal collected was dried and sized reduced using mortar and pestle. Two hundred grams of the dried powdered material was extracted with 1500 milliliters of methanol by cold maceration technique for 2 days with occasional shaking. The resultant extract was evaporated to dryness over a water bath which gave a brown solid mass. All solutions for administrations were freshly prepared using distilled water.

\section{Animals}

Male Swiss albino mice (18 - $20 \mathrm{~g}$ ) were obtained from the Animal House of the Department of Pharmacology and Therapeutics, Ahmadu Bello University Zaria, Nigeria. They were housed in cages and kept under natural day and light cycle. Standard laboratory animal diet was provided and water ad libitum and followed experimental conditions and procedures stipulated in international guidelines [12]. An ethical approval was obtained from the Ahmadu Bello University Animal Ethics Committee (no. ABUCAUC/ 2017/022).

\section{Acute toxicity study}

Median lethal dose (LD50) was determined using Organization for Economic Co-operation and Development (OECD) guideline in mice [13]. Two groups of three mice each were fasted $3 \mathrm{~h}$ prior to administration of methanol root bark extract of Acacia seyal and $2 \mathrm{~h}$ after the administration of the extract. In limit test, $5000 \mathrm{mg} / \mathrm{kg}$ was given to one mouse and observed for $48 \mathrm{~h}$. The first mouse survived, thereafter, two more mice were given same dose of extract. In all case, mice were observed during the first $30 \mathrm{~min}$ of treatment and then at intervals over $24 \mathrm{~h}$ and then daily for 14 days. The animals were monitored for tremor, convulsion, salivation, diarrhoea, sleep, behavioural changes and coma. The time of onset of toxic symptoms and disappearance were also noted. The weights of animals were determined weekly for 14 days individually.

\section{Treatments}

On the day of injection, fresh solution of BCG was prepared and administered intraperitoneally to forty mice at the dose of $0.2 \mathrm{mg} / \mathrm{kg}$. Rectal temperatures were taken at $0,4,24$ and $48 \mathrm{~h}$ after BCG administration. The mice were divided into 5 groups of 8 mice each, then monitored for signs of motion sickness for a period of $4 \mathrm{~h}$. Three hours after BCG treatment, Group 1 mice were given distilled water $(10 \mathrm{ml} / \mathrm{kg})$ and group 2 with fluoxetine $(20 \mathrm{mg} / \mathrm{kg})$ via the oral route. Mice in groups 3, 4 and 5 received methanol root bark extract of Acacia seyal at dose of 250, 500 and $1000 \mathrm{mg} / \mathrm{kg}$ per orally respectively. Mice in all groups were then subjected to tail suspension and open field test $1 \mathrm{~h}$ after treatment, with another hour interval allowed between each test.

\section{Behavioural tests}

\section{Tail suspension test}

Tail suspension test (TST) was performed according to the method described by [14]. Mice in all the groups were subjected to tail suspension test by individual suspension of the mouse $60 \mathrm{~cm}$ above the surface of the table with an adhesive tape placed $1 \mathrm{~cm}$ away from the tip of the tail and a cylindrical rubber stopper. Mice were considered immobile only when they hung passively and were completely motionless. 
Experiments were video-taped for $6 \mathrm{~min}$. This test was done at 4,24 and $48 \mathrm{~h}$ post BCG injection.

\section{Open field test}

Each mouse was placed in a white wooden open field apparatus $(70 \times 70 \times 35 \mathrm{~cm}$, length $\times$ breadth $x$ height), one side and floor were made up of transparent plexiglas, with the floor divided into 16 visible squares $(15 \times 15 \mathrm{~cm})$ with a central square. Peripheral and central square crossing behaviour of each mouse was recorded for $6 \mathrm{~min}$ with the aid of a camera suspended at the top of the apparatus [15]. This test was done at 4,24 and $48 \mathrm{~h}$ after BCG administration.

\section{Statistical analysis}

All values are expressed as mean \pm SEM. Values for rectal temperature were analysed using repeated measures ANOVA followed with Bonferroni post hoc test. The differences in the mean of immobility from tail suspension test, and mean number of line crossing activities from open field studies among different treated groups were analysed using one-way ANOVA followed by Bonferroni post hoc test using SPSS version 20.0. A value of $p<0.05$ was considered significant.

\section{RESULTS}

Median lethal dose $\left(L D_{50}\right)$ for methanol root bark extract of Acacia seyal

The $\mathrm{LD}_{50}$ was $\geq 5000 \mathrm{mg} / \mathrm{kg}$ orally in mice.

Effect of BCG on body temperature at $48 \mathrm{~h}$ post-administration

The changes in core body temperature was measured at 4,24 and $48 \mathrm{~h}$ post-BCG injection. There was a significant $(p<0.001)$ decrease in rectal temperature of mice at all tested doses 4 hours post BCG injection when compared with the rectal temperature at $0 \mathrm{~h}$. There was also a significant $(p<0.05)$ change in rectal temperature $24 \mathrm{~h}$ post-BCG injection at 1000 $\mathrm{mg} / \mathrm{kg}$ dose of extract. There was also a decrease in rectal temperature at all tested doses $48 \mathrm{~h}$ post BCG injection, when compared to the distilled water group (Figure 1).

\section{Effect of methanol root extract of acacia seyal on duration of immobility in BCG-induced depression in mice}

There were a significant $(p<0.001)$ decrease in the duration of immobility in mice treated with fluoxetine $(20 \mathrm{mg} / \mathrm{kg}$ ) and Acacia seyal (AS 500 and $1000 \mathrm{mg} / \mathrm{kg}) 4 \mathrm{~h}$ post-BCG administration. There were also significant $(p \leq 0.01)$ and dosedependent decrease in the duration of immobility at all the tested doses when compared to the distilled water group 24 hours post-BCG injection. However, only the highest dose of extract and fluoxetine were able to significantly ( $p$ $\leq 0.05$ ) decrease the duration of immobility $48 \mathrm{~h}$ post-BCG injection when compared to the distilled water group (Figure 2).

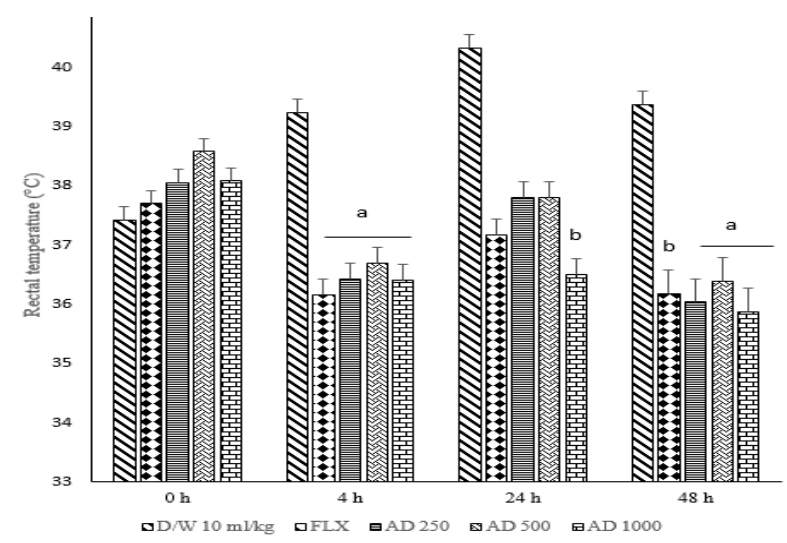

Figure 1: Effect of methanol root bark extract of Acacia seyal on BCG-induced changes in rectal temperature of mice. Note: Each column represents mean \pm S.E.M. of 8 mice. Data analysis was performed using repeated measures ANOVA followed by Bonferroni post hoc test, ${ }^{a} p<0.001$ and ${ }^{b} p<0.05$, significantly different from distilled water group at various times. $\mathrm{AS}=$ Acacia seyal, $\mathrm{DW}=$ Distilled water, FLX = Fluoxetine, $\mathrm{h}=$ hour

Effect of methanol root extract of acacia seyal on locomotory behaviour in mice on BCGinduced depression

Following BCG administration, there was a decrease in locomotor activity of mice. Treatment with methanol root extract of Acacia seyal (1000 $\mathrm{mg} / \mathrm{kg}$ ) significantly ( $p \leq 0.001)$ increased the number of line crossing in mice at $4 \mathrm{~h}$ post-BCG injection. However, significant ( $p \leq 0.001)$ increased number of line crossing at $24 \mathrm{~h}$ postBCG was exhibited by the mice treated with methanol root extract of Acacia seyal (250, 500 and $1,000 \mathrm{mg} / \mathrm{kg}$ ) as compared to the distilled water group. At the end $48 \mathrm{~h}$ post-BCG, only the standard drug fluoxetine $(20 \mathrm{mg} / \mathrm{kg})$ significantly increased locomotor activity of mice when compared with mice treated with distilled water (Figure 3).

\section{DISCUSSION}

This study established the involvement of antiinflammatory mechanism in the antidepressant activity of Acacia seyal using BCG-induced

Trop J Pharm Res, July 2020; 19(7): 1461 
depression model in mice. Bacillus CalmetteGuerin (BCG) is a vaccine primarily used against tuberculosis in healthy babies in countries where tuberculosis or leprosy is common [16]. The BCG acts by activating indoleamine 2, 3dioxygenase (IDO) in the periphery and brain which induces pro-inflammatory cytokines well known to cause clinical signs of depressive-like behaviour in both humans and animal models $[17,18]$.

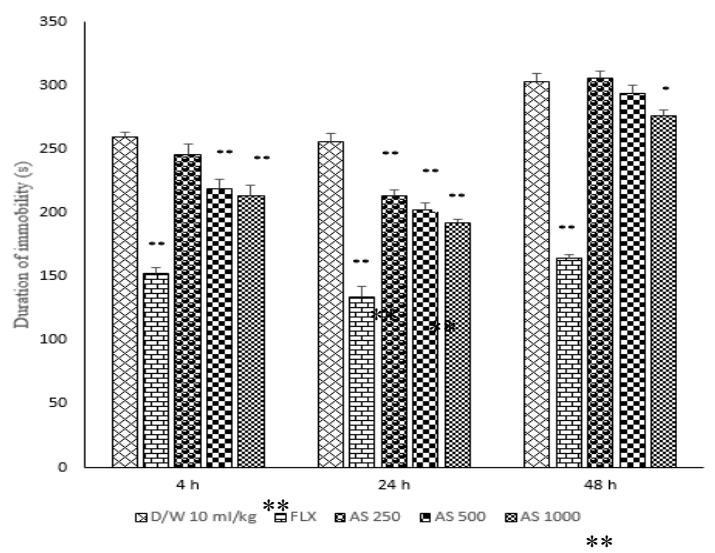

Figure 2: Effect of methanol root extract of acacia seyal on duration of immobility in the BCG-induced depression in mice. Note: All results are expressed as mean $\pm \operatorname{SEM}(n=8)$. Data were analysed using oneway ANOVA followed by Bonferoni post hoc test, ${ }^{*} p<$ 0.05 and ${ }^{* *} p \leq 0.001$ significant difference when compared to distilled water group. DW = distilled water $(10 \mathrm{ml} / \mathrm{kg}$, po $), \mathrm{AS}=$ Acacia seyal $(250,500 \& 1,000$ $\mathrm{mg} / \mathrm{kg}, p o), \mathrm{FLX}=$ Fluoxetine $(20 \mathrm{mg} / \mathrm{kg}, p o)$

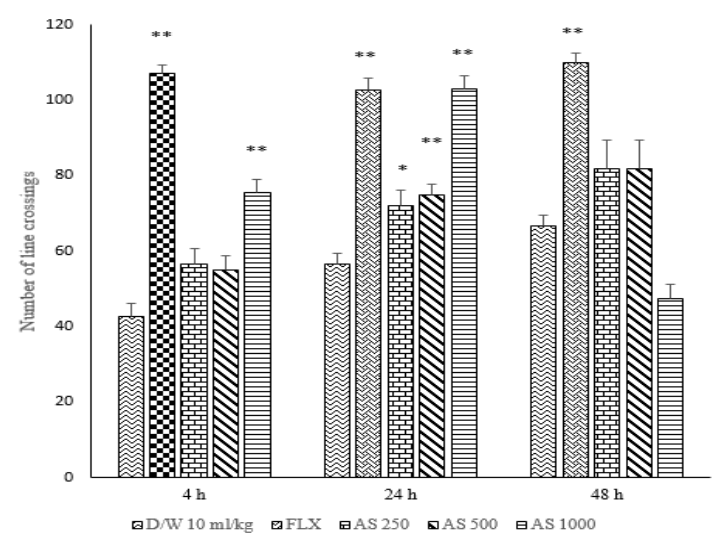

Figure 3: Effect of methanol root extract of Acacia seyal on line crossing behaviour of mice following BCG-induced depression. Note: Data were analysed using one-way ANOVA followed by Bonferoni post hoc test, expressed as mean \pm SEM $(n=8) . * p \leq 0.05$ and $* * p \leq 0.001$ significant difference when compared with distilled water group. DW = distilled water $(10 \mathrm{ml} / \mathrm{kg}$, po), AS = Acacia seyal $(250,500 \& 1,000 \mathrm{mg} / \mathrm{kg}, p o)$, $\mathrm{FLX}=$ Fluoxetine $(20 \mathrm{mg} / \mathrm{kg}, \mathrm{po}), \mathrm{h}=$ hour

Mice injected with BCG shows high levels of circulatory pro-inflammatory cytokines which was observable as sickness behaviour and increased rectal temperature usually within $4 \mathrm{~h}$ post injection. Several researches showed a close linkage between inflammation and depression $[19,20]$ and drugs with antidepressant effect decrease rectal temperature. Administration of Acacia seyal extract at $3 \mathrm{~h}$ post-BCG produced a decrease in rectal temperature indicating the effect of Acacia seyal on BCG-induced depression.

There was a decrease in duration of immobility in mice treated with methanol root bark extract of Acacia seyal extract in the tail suspension test. The tail suspension test (TST) is utilized to evaluate antidepres *nt drugs [21] and is able to detect most classes of antidepressant drugs like tricyclics, selective serotonin reuptake inhibitors (SSRIs) and monoamine oxidase inhibitors. In TST, duration immobility is the indicator behaviour which reflects behavioural despair similar to the case in human depression [22]. Thus, reduction of immobility by $A S$ is an indication * of its antidepressant activity. The concept of cytokine-induced depression-like behaviour in rodents using BCG vaccine is well established and it explains resistance to antidepressants treatment in some patients [5]. This resistance warrants the screening of alternative drugs for wider efficacy [23].

Acacia seyal extract was able to ameliorate BCG-induced depression by blocking the development of both sickness and depressivelike behaviour in treated mice. Since accumulating evidence suggests that depression is associated with an up-regulation of proinflammatory cytokines induced by BCG administration, thus $A S$ to down regulated these inflammatory cytokines and ameliorated BCGinduced depression [24]. So also, AS was reported to possess anti-inflammatory activity in models of pain further supporting the finding in this study the additional benefits in inflammation associated depression [12].

The Open field study showed that rodent develop fear for open areas against their desire to explore new environments [25]. The open field test was carried out to determine the effect of the extract on spontaneous locomotor activity since the BCG has the ability to impair locomotor behaviour in addition to the depressive episodes [26]. The number of squares crossed are usually used as measures of locomotor activity, exploration and anxiety. In this study, treatment with AS increased line crossing activity indicating its ability to reverse the altered locomotion by BCG. The oral median lethal dose of the extract was

Trop J Pharm Res, July 2020; 19(7): 1462 
found to be $5000 \mathrm{mg} / \mathrm{kg}$ suggesting its relative safety as described by the OECD guideline [13].

\section{CONCLUSION}

The methanol root bark extract of Acacia seyal possesses significant antidepressant activity possibly mediated via anti-inflammatory mechanisms. The root bark of the plant Acacia seyal can be used in the management of depression resistant to other conventional antidepressant agents.

\section{DECLARATIONS}

\section{Acknowledgement}

The technical help of Messrs Bashir Shehu and Abubakar Balarabe of the Department of Pharmacology and Therapeutics, ABU Zaria is acknowledged.

\section{Conflict of interest}

No conflict of interest is associated with this work.

\section{Contribution of authors}

We declare that this work was done by the authors named in this article and all liabilities pertaining to claims relating to the content of this article will be borne by the authors.

\section{Open Access}

This is an Open Access article that uses a funding model which does not charge readers or their institutions for access and distributed under the terms of the Creative Commons Attribution License (http://creativecommons.org/licenses/by/ 4.0) and the Budapest Open Access Initiative (http://www.budapestopenaccessinitiative.org/rea d), which permit unrestricted use, distribution, and reproduction in any medium, provided the original work is properly credited.

\section{REFERENCES}

1. Rainville JR, Hodes GE. Inflaming sex differences in mood disorders. Neuropsychopharmacology 2019; 44(1): 184-199. doi: 10.1038/s41386-018-0124-7.

2. Miloyan B, Fried E. A reassessment of the relationship between depression and all-cause mortality in 3,604,005 participants from 293 studies. World Psychiatry 2017; 16(2): 219-220. doi: 10.1002/wps. 20439.

3. Luo Y, Kuang S, Li H, Ran D, Yang J. cAMP/PKA-CREB$B D N F$ signaling pathway in hippocampus mediates cyclooxygenase 2-induced learning/memory deficits of rats subjected to chronic unpredictable mild stress. Oncotarget 2017; 8(22): 35558-35572. doi: 10.18632/oncotarget.16009.

4. Fried El. (2017). Moving forward: how depression heterogeneity hinders progress in treatment and research. Expert Rev Neurotherapeut, http://dx.doi.org/10.1080/14737175.2017.1307737

5. Fajemiroye JO, da Silva DM, Costa EA. Treatment of anxiety and depression: medicinal plants retrospect. Fund Clin Pharmacol 2016, 30(30): 198-215.

6. Holzer $P$, Farzi A, Hassan AM, Zenz $G$, Jačan A, Reichmann F. Visceral Inflammation and Immune Activation Stress the Brain. Front Immunol 2017; 8: 1613. doi: 10.3389/fimmu.2017.01613. eCollection 2017.

7. O'Connor JC, Lawson MA, Andre C, Moreau M, Lestage $J$, Castanon N, Kelley KW, Dantzer $R$. Lipopolysaccharide-induced depression-like behaviour is mediated by indoleamine 2,3-dioxygenase activation in mice. Mol Psychiatry 2009; 14: 511-522.

8. Mechawar N, Savitz J. Neuropathology of mood disorders: do we see the stigmata of inflammation? Transl Psychiatry 2016; 8: 6(11): e946. doi: 10.1038/tp.2016.212.

9. Andrew HM, Charles LR. The role of inflammation in depression: from evolutionary imperative to modern treatment target. Nat Rev Immunol 2016; 16(1): 22-34. doi: 10.1038/nri.2015.5

10. Devorak J, Susana GT, Antonietta M, Davoli P, Gustavo $T$, Naguib M. Cellular and molecular inflammatory profile of the choroid plexus in depression and suicide. Front Psychiatry 2015; 6: 138. doi: 10.3389/fpsyt.2015.00138.

11. Shehu A, Magaji MG, Yau J, Abubakar A. Ethnobotanical survey of medicinal plants used for the management of depression by Hausa tribes of Kaduna State, Nigeria. J Med Plants Res 2017; 11(36): 562-567.

12. Bayne KA. Potential for unintended consequences of environmental enrichment for laboratory animals and research results. ILAR J. 2005; 46:129-139.

13. Elnour AAM, Mirghani MES, Kabbashi NA, Alam Z, Musa $K H$. Study of antioxidant and anti-inflammatory crude methanol extract and fractions of Acacia seyal Gum. J Pharmacol Pharmacother 2018; 5: 1-3. DOI: 10.21767/2393-8862.100012

14. OECD 425. Acute oral toxicity: Up and down procedure. Guideline for the Testing of Chemicals 2008; pp. 1-2.

15. Steru L, Chermat R, Thierry B, Simon P. The tail suspension test: a new method for screening antidepressants in mice. Psychopharmacol 1985; 85: 367-370.

16. Rex A, Voigt JP, Voits $M$, Fink $H$. Pharmacological evaluation of a modified open field test sensitive to anxiolytic drugs. Pharmacol Biochem Behav 1998; 59: 677-683.

17. Trunz BB, Fine PEM, Dye C. Effect of BCG vaccination on childhood tuberculous meningitis and miliary tuberculosis worldwide: a meta-analysis and

Trop J Pharm Res, July 2020; 19(7): 1463 
assessment of cost-effectiveness. Lancet Infect 2006; 367(9517): 1173-1180.

18. Moreau M, Andre C, O'Connor JC, Dumich SA, Woods $J A$, Kelley KW, Dantzer R, Lestage J, Castanon N. (2008). Inoculation of Bacillus Calmette-Guerin to mice induces an acute episode of sickness behavior followed by chronic depressive-like behavior. Brain Behav Immun; 22: 1087-1095.

19. Moreau M, Lestage J, Verrier D, Mormede C, Kelley KW, Dantzer R, Castanon N. Bacille Calmette-Guerin inoculation induces chronic activation of peripheral and brain indoleamine 2,3-dioxygenase in mice. J Infect Dis 2005;192: 537-544.

20. Galecki P, Galecka E, Maes M, Chamielec $M$, Orzechowska A, Bobiriska K, Lewinski A, Szemraj J. The expression of genes encoding for COX-2, MPO, iNOS and SPLA2-IIA in patients with recurrent depressive disorder. J Affect Disord 2012; 138:360-366.

21. Patki G, Solanki N, Atrooz F, Allam F, Salim S. Depression, anxiety-like behaviour and memory impairment are associated with increased oxidative stress and inflammation in a rat model of social stress. Brain Res 2013; S0006-8993(13): 01307-01313.
22. Zeugmann S, Buehrsch $N$, Bajbouj M, Heuser I, Anghelescu I, Quante A. Childhood maltreatment and adult proinflammatory status in patients with major depression. Psychiatr Danub 2013; 25: 227-235.

23. Petit-Demouliere B, Chenu F, Bourin M. Forced swimming test in mice: a review of antidepressant activity. Psychopharmacol 2005; 177: 245-255.

24. Lopresti AL, Maker GL, Hood SD, Drummond PD. A review of the peripheral biomarkers in major depression: the potential of inflammatory and oxidative stress biomarkers. Prog Neuropsychopharmacol Biol Psychiatry 2014; 48: 102-111.

25. Hsu LKY, Cheng H, Chang C, Lin Y, Hsieh M, Peng WH. Antidepressant-like activity of the ethanolic extract from Uncaria lanosa Wallich Var appendiculata Ridsd in the forced swimming test and tail suspension test in mice. Evid Based Complementary Altern Med 2012; 2012: 112.

26. Evelin P, Martin JK, Aitak F, Ulrich SD, Frank S, Herbert H, Peter H. (2013). Neuropeptide $Y$ and peptide $Y Y$ protect from weight loss caused by Bacille CalmetteGuérin in mice. Br J Pharmacol 2012; 170: 1014-1026. 